\title{
DASUN REMBANG: TENGGELAM DAN BANGKIT
}

\author{
Muhtar Said \\ Ilmu Hukum Universitas Nahdlatul Ulama Indonesia \\ Email: said@unusia.ac.id
}

\begin{abstract}
ABSTRAK
Desa Dasun merupakan desa yang mempunyai sejarah Panjang karena merupakan pintu masuk Kota Lasem, Rembang dari wilayah pesisir utara. Meskipun pernah meraih kejayaan karena menjadi pusat perekonomian pada zaman dahulu kemudian tenggelam oleh zaman. Namun seiring waktu Desa Dasun mulai menuju kebangkitan.

Kata Kunci : Dasun, Lasem, Rembang

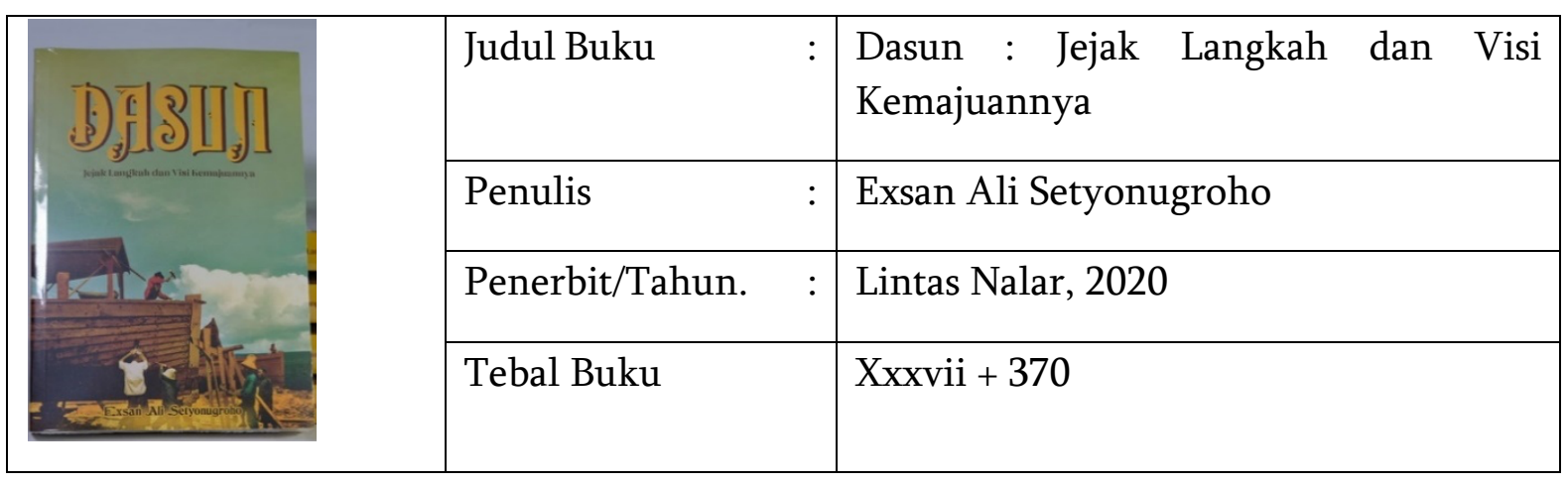

Buku yang berjudul "Dasun: Jejak Langkah dan visi Kemajuannya" ini bisa membuat banyak orang terjebak ketika hanya melihat cover dan judulnya saja karena yang terngiang dalam pikiran ketika mulihat buku ini hanyalah uraian kata terkait dengan Profil visi-misi Desa Dasun. Namun, ketika buku ini dibaca dari lembar pertama sampai dengan dipertengahan maka pembaca akan merasa takjub karena buku ini ditulis dengan menggunakan pendekatan genealogi. Menukil istilah genealogi Michael Foucoult maka metode penulisan dalam buku ini lebih mendekati genealogi yang pernah dipopulerkan oleh filsuf dari Perancis tersebut, yakni menggali cerita cerita rakyat yang kemudian disandingkan dengan dokumen - dokumen yang ditemukan oleh penulis.

Artinya penulis menelusuri secara mendalam asal asul Desa Dasun dengan menyandingkan cerita-cerita rakyat kemudian cerita tersebut diuji kebenarannya dengan dokumen yang dicari dibeberapa perpustakaan. Sehingga buku ini bukan menemukan sebuah solusi layaknya Desertasi tetapi lebih cenderung menyajikan gambaran-gambaran saja. Dan memang buku ini diniatkan untuk itu. 
Isi dalam buku ini terkait dengan sejarah panjang kejayaan Desa Dasun, Rembang. Dimana desa ini merupakan pintu masuk Kota Lasem dari wilayah pesisir hal itu berhasil dibuktikan oleh penulis melalui dokumen dokumen berupa peninggalan galangan kapal.

Seolah penulis ingin menggali dan menelusuri sejarah Desa Dasun yang kemudian akan dijadikan pondasi membuat visi-misi Desa Dasun ke Depan. Hal ini diketahui dengan tulisan pada Bab III, dalam bagian ini penulis mengulik secara detail asal usul nama Desa Dasun, seperti dijelaskan di atas, Penulis menelusuri cerita rakyat yang kemudian disandingkan dengan beberapa dokumen yang telah diterbitkan. Bahkan ketika buku ini mendapat pujian dari Hasyim Asyari, Seorang Dosen Fakultas Hukum Universitas Diponegoro Semarang yang juga pernah penulis Genealogi perjuangan Lembaga Bantuan Hukum yang bernaung dalam Yayasan Lembaga Bantuan Hukum Indonesia (YLBHI). Hasyim Asyari sekilas membaca buku ini kemudian muncul kata-kata "penulis benar-benar niat dalam menulis buku ini". Hal ini menunjukan penulis serius dalam mengungkap sejarah Desan Dasun.

Meskipun demikian ada sisi-sisi subjektif dalam buku ini karena penulis merupakan Sekretaris Desa Dasun, sehingga niat dalam menbuat buku ini adalah untuk mengangkat kejayaan Desa Dasun yang sudah lama tenggelam oleh zaman. Metode seperti ini tidak salah, karena sejarah adalah pondasi dasar untuk meniti pembangunan, bahwa pembanguna tidak boleh lepas dari sejarah supaya tidak tercerabut ruh dan akar budayanya, sehingga buku ini juga menjadi semacam garis atau tembok pembatas bagi pemimpin Desa Dasun untuk membuat visi dan misi pembangun Desa Dasun.

Hal yang menarik dari buku ini juga tidak hanya bercerita soal Desa Dasun tetapi sejarah panjang Kota Lasem dan sekitarnya bahkan juga bercerita soal kerajaan-kerajaan yang mempengaruhi perkembangan Kota Lasem dan sekitarnya. sehingga bisa juga menjadi rujukan bagi para penikmat sejarah 